\title{
Sustainable Development Based on Green GDP Accounting and Cloud Computing: A Case Study of Zhejiang Province
}

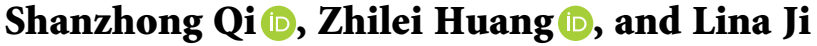 \\ College of Geography and Environment, Shandong Normal University, Jinan 250358, China \\ Correspondence should be addressed to Shanzhong Qi; shzhqi@sdnu.edu.cn and Zhilei Huang; qshzhsd@163.com
}

Received 9 August 2021; Accepted 4 September 2021; Published 23 September 2021

Academic Editor: Punit Gupta

Copyright ( 2021 Shanzhong Qi et al. This is an open access article distributed under the Creative Commons Attribution License, which permits unrestricted use, distribution, and reproduction in any medium, provided the original work is properly cited.

\begin{abstract}
Cloud computing is a supercomputing that integrates large-scale and scalable computing, storage, data, applications, and other distributed computing resources for collaborative work in the form of virtualization technology as the basis and the network as the carrier to provide infrastructure, platform, software, and other service's model. Green GDP (GGDP) is an assessment indicator for regional sustainable development. Hence, the evaluation index on GGDP and greening of the national economic accounting system (SNA) are the hotspots of current ecological and economic studies. In the recent years, Zhejiang's economy has achieved rapid development, and there are also problems of high input and high consumption of natural resources, thereby restricting its sustainable development. Based on the statistical data of Zhejiang Province during 2000-2017, the GGDP within the sustainable development context is calculated using the system of integrated environmental and economic accounting (SEEA). The results indicated the following: (1) The GGDP accounted for 79.29\%-96.78\% of Zhejiang's GDP during the study period, which showed volatility upward trend, resulting from the significant environmental protection and conservation of natural resources in the study area. But economic development was heavily dependent on resources, and the local government still strengthened the work of improving resources and environment. (2) The proportion of secondary industry in Zhejiang Province fluctuated downwards during the period of 2000-2017, and the tertiary industry showed a volatility upward trend, which exceeded the proportion of the secondary industry, indicating that Zhejiang Province is from an industry-led economy to a service-oriented economy change. (3) The GGDP of Zhejiang Province accounted for the highest proportion of GDP in 2008, resulting from the result of a combination of relevant national policies and international competitions.
\end{abstract}

\section{Introduction}

Gross domestic product (GDP) is an important index and expounds sustainable development within economic, social, and environmental contexts. In his book Economics, Samuelson stated that GDP is one of the greatest inventions of the twentieth century [1], and it is the sum of the values of all services and products which are produced by a country or region in a certain period, and it is a key indicator to evaluate the economic development level for a country or region [2]. For a long time, people have overestimated the positive effect of GDP on promoting economic and social development. Blind pursuit of GDP growth has caused great waste of natural resources and environmental damage. Increasing environmental problems have aroused widespread concern in all countries around the world. In order to achieve sustainable development, governments have actively carried out green GDP (GGDP) accounting projects to compensate for the shortcomings of the original GDP accounting and to reflect more fully and truly the level of national development [3]. GGDP refers to the remaining gross domestic product after deducting the depletion value of ecological resources, such as resource consumption and environmental pollution from traditional GDP [4], which is a compelling method to combine various types of environmental impact with growth within economic context. GGDP can be used to reflect economic growth, to account for the natural resources and environmental conditions, and to allow comparison across countries [5]. GGDP is a compelling approach for combining various types of environmental impact with growth from the economic perspective, and it 
is an indicator of economic growth with the environmental impacts on that growth factored into the traditional GDP.

Since the 1970s, governments, experts, and scholars have noticed the importance of GGDP and conducted a lot of researches [6]. In 1993, the United Nations Statistical Institute firstly proposed the concept of GGDP in its the System of Integrated Environmental and Economic Accounting (SEEA), which included the integration of resources and environmental costs into the production of the national economy, as the cost of economic production to achieve the adjustment of the original GDP [7]. In addition, the internationally established GGDP accounting system includes the European Statistical Office's European Economic Information Collection System (SERIEE) [8], the Philippine Environmental and Natural Resources Accounting System (ENRAP) [9], and the National Statistical Office of the Netherlands, including the National Accounts Matrix System for Environmental Accounts (NAMEA) [10]. Costanza et al. (1997) measured the service value of the global natural environment for human beings, that is, the ecological service index system (ESI) [11], and Dasily et al. (2000) put forward to evaluate and effectively manage the value of the natural ecosystem, which provides an effective reference for the GGDP accounting [12].

Since the 1990s, Chinese scholars have achieved fruitful results in GGDP theory $[13,14]$, system construction $[15,16]$, accounting methods [17-20], and empirical studies [21-23]. Lei (1998) took the lead in designing a resourceeconomic integration accounting input-output table, taking coal resources as an example to measure China's 1992 GGDP at the national and provincial levels [16]. Shen et al. (2017) used the SEEA system to measure the GGDP of 31 provinces (municipalities and autonomous regions) in China and mainland China from 1997 to 2006 and analysed the spatial pattern according to per capita GGDP and GGDP index [23]. Zhang et al. (2010) used the energy value analysis method to calculate the GGDP of Fujian Province from 2001 to 2006 and used some energy value evaluation indicators to analyze the sustainable development [22]. Lei et al. (2009) calculated the GGDP of Yulin City, Shaanxi Province, by constructing a resource and environmental account index system at the municipal level [21]. Based on the energy value analysis method, Guo et al. (2015) carried out the GGDP accounting of Shangluo city, Shaanxi Province, during the period of 2003-2012 [24]. The GGDP accounting method is mainly divided into two types, namely, direct measurement algorithm and indirect measurement algorithm. The direct measurement algorithm can be calculated by the production method and the expenditure method $[19,20]$. The indirect measurement algorithm integrates the resource, environment, and economic factors on the basis of the traditional GDP accounting and obtains the adjustment of the traditional GDP data [25]. It can be found that most accounting studies on the current GGDP are concentrated on the resource-based city level, lacking studies on the GGDP of Zhejiang Province.

Zhejiang Province is a province with the smallest differences within economic development context in China. For example, the GDP per capita in Zhejiang Province is basically above the national level and the per capita disposable income of rural and urban residents for decades is the first among all provinces and cities in China. During the period of 2000-2017, its economy has achieved rapid development, and there are also problems of high input and high consumption of natural resources, thereby restricting Zhejiang's sustainable development. At the same time, the studies are mostly concentrated in a single year from the time scale, or the time span is only 5-10a. Lack of long-term researches may lead to insignificant trends in GGDP. From the perspective of sustainable development, this study aims to introduce a GGDP accounting index system for Zhejiang Province by using the method of SEEA to calculate Zhejiang's GGDP from 2000 to 2017. Further, this study should present a scientific basis for Zhejiang Province to formulate some strategies on its social and economic development and achieve the sustainable development of Zhejiang's resources, environment, economy, and society.

\section{Methodology}

2.1. Study Area. Zhejiang Province $\left(27^{\circ} 03^{\prime} \sim 31^{\circ} 11^{\prime} \mathrm{N}\right.$ and $\left.118^{\circ} 01^{\prime} \sim 123^{\circ} 25^{\prime} \mathrm{E}\right)$ is located in the south wing of the Yangtze River Delta on the southeast coast of China, with an area of $105,500 \mathrm{~km}^{2}$ and a total population of $49,576,300$ (2017). Zhejiang's terrain is stepped from southwest to northeast, with mountains in the southwest, hills in the middle, and alluvial plains in the northeast, and it has a subtropical monsoon climate with four distinct seasons with the annual average temperature of $15-18^{\circ} \mathrm{C}$ and the annual average rainfall of $980-2000 \mathrm{~mm}$. In the past 18 years, Zhejiang's economy has achieved rapid development, and there are also problems of high input and high consumption of natural resources. In 2017, its GDP achieved 517.768 billion yuan, 8.43 times in 2000, and its average annual GDP growth is $12.1 \%$ during $2000-2017$. In the same period, the consumption of natural resources increased year by year. In 2000, the total energy consumption of the whole province was 65.6037 million tons of standard coal. In 2017, it reached 210.3001 million tons of standard coal. In the past 18 years, the consumption of energy increased by 3 times, and the average annual growth of energy consumption increased by $7.4 \%$. With the development of industry, the "three wastes" produced by enterprises have a greater negative impact on the environment. In 2017, the industrial exhaust emissions were 3131 billion standard cubic meters, an increase of 4.8 times over 2000, and the industrial solid waste generated 48.28 million tons, an increase of 3.5 times over 2000. If resources and environmental factors are incorporated into the national economic accounting system, traditional GDP will shrink significantly.

2.2. GGDP Accounting Methods. For the accounting of GGDP, the SEEA [26] is commonly used to illustrate the relationship among GDP, environment, and resources; that is, the natural GDP depletion cost and environmental quality degradation cost are subtracted from the gross domestic 
product, and the resource environment is improved to obtain GGDP as shown

$$
\begin{aligned}
\mathrm{GGDP}= & \mathrm{GDP}-\mathrm{COST}_{\text {Resources }}-\mathrm{COST}_{\text {Environment }} \\
& +\mathrm{SAVE}_{\text {Resources-Environment, }}
\end{aligned}
$$

where $\operatorname{COST}_{\text {Resources }}$ represents the natural resource depletion cost, COST $_{\text {Environment }}$ represents the environmental quality degradation cost, and $\mathrm{SAVE}_{\text {Resources-Environment }}$ represents the resource environment improvement benefit.

2.3. Indicator Selection of GGDP Accounting. Based on the previous study results, this study combines the main types of natural resource consumption in Zhejiang Province in the past 18 years, classifies the accounts of GGDP accounting into three categories, and selects 10 indicators. The accounting for the depletion of natural resources can be divided into 5 major types of natural resource consumption. The specific indicators are the value of cultivated land depletion, the value of depletion of forest resources, the value of depletion of water resources, the value of energy depletion, and the depletion of mineral resources. The accounting for environmental quality degradation costs is to select various indicators that have a significant impact on the ecological environment of Zhejiang Province, which can be divided into air pollution, water pollution, solid waste pollution, and natural disaster losses. Since the benefits of resource environment improvement are multifaceted and the data are limited, this study only considers the benefits of garden green space, which may have a low impact on the final accounting results.

The evaluation on the depletion value of cultivated land is based on the income multiple method, namely, to calculate the average output value of the first three years of cultivated land and then multiply by the comprehensive maximum multiple of the land compensation fee and resettlement subsidy standard as stipulated in Article 47 of the Land Administration Law, thereby getting the total value of cultivated land, which is divided by the area of cultivated land, and finally get the price of cultivated land per unit area. Finally, by multiplying the obtained cultivated land price per unit area by the cultivated land change area of each year, the value of cultivated land consumption can be obtained [27].

The international common experience method is often used for the value of water resources depletion. The estimation formula is as follows:

$$
\mathrm{P}_{\mathrm{w}}=\frac{\mathrm{F}}{\mathrm{Q}} \alpha
$$

where $\mathrm{P}_{\mathrm{w}}$ refers to the price of water resources, $\mathrm{F}$ refers to the total value created by producers in the water industry (considering the availability of data, F is roughly displaced by the annual GDP increase of Zhejiang Province), $Q$ refers to the total amount of water used each year, and a refers to the consumer's willingness to pay factor. This study does not distinguish between the water industries in the study area and directly estimates the entire area as a whole. According to the formula of the per capita water resources and the empirical method of the willingness coefficient of payment in Zhejiang and other cities from 2000 to 2017, the value is $3 \%$ [27].

For the energy depletion value in this study, we use the price of standard coal in 2004, namely, 1,133 yuan/ $t$ [28], and then revise through the historical energy price index to obtain the unit energy price in Zhejiang Province over the years from 2000 to 2017.

Exhaust gas, waste water, and solid waste are substances that have a direct negative impact on environment in daily production and life. Considering the availability of data, the objects to be calculated in this study include sulfur dioxide in exhaust gas, smoke dust, industrial wastewater and domestic wastewater in wastewater, industrial solid waste, and domestic waste in solid waste, of which the amount of industrial solid waste is obtained according to the Production Amount-Comprehensive Utilization Amount, and the amount of domestic garbage is obtained according to the Clearance Amount-Harmless Treatment Amount [23]. For the unit treatment cost of various pollutants, the unit cost of sulfur dioxide treatment will be determined according to the 20000 yuan/ $t$ formulated by Jiaxing City in the implementation of emissions trading in 2007 [29]. Other governance costs are based on the current year's parameters in the existing study and adjusted according to the historical consumer price index (CPI), so that the average unit cost of smoke dust is 170 yuan/ $t$ [30]. When calculating the pollution price, according to the Guidelines for China's Environmental Economic Accounting Technology, the unit treatment cost of industrial wastewater is 4.02 yuan $/ t$, and the unit treatment cost of domestic wastewater is 0.6 yuan $/ t$ [31]. The solid waste adopts the national unified standard parameters in 2004; that is, the unit treatment cost of industrial solid waste is 20 yuan/t [32], and the domestic garbage disposal cost is determined to be 110 yuan/ $t$ based on the Hangzhou municipal garbage collection and treatment cost report issued by the World Bank in 2002 [29]. Due to the incomplete statistics of pollutants, the results are low. Under the guidance of SEEA, through the above analysis, the accounting method of green GDP in this paper is established (Table 1).

2.4. Data Source. In this study, the data were mainly obtained from the Chinese Statistical Yearbook (National Bureau of Statistics of the People's Republic of China 2001-2018), the Zhejiang Statistical Yearbook (Zhejiang Province Bureau of Statistic 2001-2018), the China Land and Resources Statistical Yearbook (Ministry of Land and Resources of the People's Republic of China 2001-2018), and related literature.

A size of $150 \mathrm{~mm} \times 150 \mathrm{~mm} \times 550 \mathrm{~mm}$ was used for pore pressure tests. After casting, all the specimens were stored in a standard curing room of concrete with molds for 24 hours; thereafter they were demoded, subjected to water of $20^{\circ} \mathrm{C}$, and cured for 28 days. The initial moisture of the specimens was between 4 and $5 \%$ by mass. 
TABLE 1: Accounting methods of GGDP.

\begin{tabular}{|c|c|c|}
\hline Account type & Index & Calculation methods \\
\hline \multirow{5}{*}{ Natural resource depletion cost } & $\begin{array}{l}\text { Cultivated land } \\
\text { depletion value }\end{array}$ & Cultivated land depletion value $=$ cultivated land consumption $\times$ unit price \\
\hline & $\begin{array}{l}\text { Forest resource } \\
\text { depletion value }\end{array}$ & Forest resource depletion value $=$ forest land consumption $\times$ unit price \\
\hline & $\begin{array}{l}\text { Water resource } \\
\text { depletion value }\end{array}$ & $\begin{array}{c}\text { Water resource depletion value }=\text { total water use } \times \text { unit volume consumers } \\
\text { willing to pay the price }\end{array}$ \\
\hline & $\begin{array}{l}\text { Energy consumption } \\
\text { value }\end{array}$ & Energy consumption value $=$ total energy consumption $\times$ unit energy price \\
\hline & $\begin{array}{l}\text { Mineral resource } \\
\text { depletion value }\end{array}$ & $\begin{array}{l}\text { Mineral resource depletion value }=\text { mineral resource consumption } \\
\text { reduction } \times \text { unit mineral price }\end{array}$ \\
\hline \multirow{5}{*}{$\begin{array}{l}\text { Environmental quality } \\
\text { degradation cost }\end{array}$} & Air pollution & $\begin{array}{c}\mathrm{SO}_{2} \text { governance costs }=\mathrm{SO}_{2} \text { emissions } \times \text { unit } \mathrm{SO}_{2} \text { management fee } \\
\text { Smoke dust treatment cost }=\text { smoke dust emissions } \times \text { unit smoke dust treatment } \\
\text { costs }\end{array}$ \\
\hline & Water pollution & $\begin{array}{c}\text { Industrial wastewater treatment cost }=\text { industrial wastewater discharge } \times \text { unit } \\
\text { industrial wastewater treatment costs } \\
\text { Domestic wastewater treatment cost }=\text { domestic wastewater discharge } \times \text { unit } \\
\text { domestic wastewater treatment costs }\end{array}$ \\
\hline & & $\begin{array}{l}\text { Industrial solid waste treatment costs }=\text { industrial solid waste } \times \text { unit solid waste } \\
\text { treatment costs }\end{array}$ \\
\hline & Solid waste pollution & $\begin{array}{c}\text { Domestic waste treatment cost }=\text { amount of domestic garbage } \times \text { unit } \\
\text { management cost }\end{array}$ \\
\hline & Natural disaster loss & $\begin{array}{c}\text { Direct economic losses caused by natural disasters (geological disasters and } \\
\text { forest fires) }\end{array}$ \\
\hline $\begin{array}{l}\text { Resource and environment } \\
\text { improvement benefits }\end{array}$ & $\begin{array}{l}\text { Garden green space } \\
\text { benefits }\end{array}$ & $\begin{array}{c}\text { Carbon fixation and oxygen release efficiency }=\text { green } \\
\text { area } \times(328.5 \times 40.94 \times \text { average dollar exchange rate for the year }+12 \times 400)[27] \\
\text { Absorbing } \mathrm{SO}_{2} \text { economic benefits }=\text { green area } \times 0.296 \times 600[27] \\
\text { Regulating climate economic benefits }=\text { green area } \times 0.9 \times 24 \times 189 \times 0.7\end{array}$ \\
\hline
\end{tabular}

\section{Results and Discussion}

3.1. Analysis of GGDP in Zhejiang Province from 2000 to 2017. According to the GGDP accounting method, relevant data analysis is carried out to obtain the proportion of GGDP and GGDP in GDP of Zhejiang Province from 2000 to 2017 (Table 2). From Table 2, its GDP increased from 614.103 billion yuan in 2000 to 517.768 billion yuan in 2017. The GGDP increased from 5,047.34 billion yuan in 2000 to 481.184 billion yuan in 2017. Moreover, GGDP and GDP maintain a synchronous growth trend (Figure 1), and the proportion of GGDP to GDP generally shows an upward trend, with fluctuations in individual years. The proportion of GGDP to GDP was between $79.29 \%$ and $96.78 \%$, with the lowest proportion in 2001, reaching 79.29\%; in 2008 the proportion reached the highest, at $96.78 \%$.

From the accounting indicators that constitute GGDP, natural resource depletion costs dominate the GGDP, from 94.214 billion yuan in 2000 to 371.168 billion yuan in 2017 . The volatility directly determines the proportion of GGDP to GDP. For example, in 2001, the natural resource depletion cost was 128.344 billion yuan, accounting for the highest value of $18.61 \%$ of GDP, making the proportion of GGDP to GDP lower to the lowest point of $79.29 \%$. On the contrary, in 2008, the natural resource consumption reduction cost was reduced linearly to 53.35 billion yuan, accounting for $2.49 \%$ of the lowest value in the history, making GGDP account for $96.78 \%$ of the highest value of GDP. It dominates the proportion of GGDP to GDP. At the same time, the cost of environmental quality degradation has shown a trend of rising first and then falling, but its proportion of GDP has been declining year by year. It has decreased from $3.00 \%$ of GDP in 2000 to $0.21 \%$ in 2017 , reaching the lowest level in history, indicating research. The environmental quality of the district is improving year by year, and environmental protection work has achieved remarkable results. In addition, although the efficiency of resource and environment improvement has increased year by year, from 3.297 billion yuan in 2000 to 16.619 billion yuan in 2017, its proportion of GDP has increased first and then decreased, indicating that Zhejiang Province should pay attention to resource and environmental improvement to enhance the efficiency of resources and environment. It can be seen that, in 2000-2017, the resource conservation effect of Zhejiang Province was remarkable, and the dependence of economic development on natural resources was gradually weakening, but it is still necessary to further promote the comprehensive utilization of resources.

From the internal analysis of accounting indicators, in the natural resource depletion cost, the energy consumption reduction value accounted for the largest proportion, reaching 62.01-85.83\%, which shows that Zhejiang Province has greater dependence on energy during the economic development and should be reduced in the future. The dependence on energy resources is a breakthrough to optimize sustainable development. Among the costs of environmental quality degradation, the cost of $\mathrm{SO}_{2}$ treatment in air pollution is the main factor. It can be seen that 
TABLE 2: Value of Zhejiang GGDP accounting indicators and the proportion of GDP during 2000-2017.

\begin{tabular}{|c|c|c|c|c|c|c|c|c|c|}
\hline & $\begin{array}{l}\text { Natural } \\
\text { resources } \\
\text { depletion } \\
\text { costs } \\
\left(10^{8} \text { yuan }\right)\end{array}$ & $\begin{array}{l}\text { Natural } \\
\text { resources } \\
\text { depletion } \\
\text { costs } \\
\text { accounted } \\
\text { for \% of } \\
\text { GDP }\end{array}$ & $\begin{array}{c}\text { Environmental } \\
\text { quality } \\
\text { degradation } \\
\text { cost }\left(10^{8} \text { yuan }\right)\end{array}$ & $\begin{array}{c}\text { Environmental } \\
\text { quality } \\
\text { degradation } \\
\text { costs accounted } \\
\text { for } \% \text { of GDP }\end{array}$ & $\begin{array}{l}\text { Resource and } \\
\text { environment } \\
\text { improvement } \\
\text { benefits } \\
\left(10^{8} \text { yuan }\right)\end{array}$ & $\begin{array}{l}\text { Resource and } \\
\text { environment } \\
\text { improvement } \\
\text { benefits } \\
\text { accounted for } \\
\% \text { of GDP }\end{array}$ & $\begin{array}{c}\text { GDP } \\
\left(10^{8} \text { yuan }\right)\end{array}$ & $\begin{array}{c}\text { Green } \\
\text { GDP } \\
\left(10^{8} \text { yuan }\right)\end{array}$ & $\begin{array}{c}\text { Green GDP } \\
\text { as a } \\
\text { percentage } \\
\text { of GDP }\end{array}$ \\
\hline 2000 & 942.14 & 15.34 & 184.52 & 3.00 & 32.97 & 0.54 & 6141.03 & 5047.34 & 82.19 \\
\hline 2001 & 1283.44 & 18.61 & 182.87 & 2.65 & 37.80 & 0.55 & 6898.30 & 5469.80 & 79.29 \\
\hline 2002 & 1189.02 & 14.86 & 193.79 & 2.42 & 45.22 & 0.56 & 8003.70 & 6666.11 & 83.29 \\
\hline 2003 & 1400.19 & 14.43 & 218.19 & 2.25 & 53.51 & 0.55 & 9705.02 & 8140.15 & 83.88 \\
\hline 2004 & 1576.11 & 13.53 & 234.42 & 2.01 & 59.92 & 0.51 & 11648.70 & 9898.09 & 84.97 \\
\hline 2005 & 1601.94 & 11.94 & 254.48 & 1.90 & 68.66 & 0.51 & 13417.70 & 11629.94 & 86.68 \\
\hline 2006 & 1992.66 & 12.68 & 256.50 & 1.63 & 70.53 & 0.45 & 15718.47 & 13539.84 & 86.14 \\
\hline 2007 & 2193.52 & 11.70 & 246.81 & 1.32 & 75.06 & 0.40 & 18753.73 & 16388.45 & 87.39 \\
\hline 2008 & 533.50 & 2.49 & 235.18 & 1.10 & 77.80 & 0.36 & 21462.69 & 20771.81 & 96.78 \\
\hline 2009 & 2054.92 & 8.94 & 229.16 & 1.00 & 78.47 & 0.34 & 22998.58 & 20792.97 & 90.41 \\
\hline 2010 & 2766.57 & 9.97 & 224.97 & 0.81 & 83.76 & 0.30 & 27747.65 & 24839.87 & 89.52 \\
\hline 2011 & 2679.53 & 8.28 & 219.44 & 0.68 & 107.97 & 0.33 & 32363.38 & 29572.38 & 91.38 \\
\hline 2012 & 3154.83 & 9.08 & 210.16 & 0.60 & 120.64 & 0.35 & 34739.13 & 31494.79 & 90.66 \\
\hline 2013 & 3074.90 & 8.14 & 198.78 & 0.53 & 125.58 & 0.33 & 37756.58 & 34608.48 & 91.66 \\
\hline 2014 & 3119.37 & 7.76 & 190.06 & 0.47 & 127.57 & 0.32 & 40173.03 & 36991.17 & 92.08 \\
\hline 2015 & 3345.63 & 7.80 & 183.39 & 0.43 & 134.37 & 0.31 & 42886.49 & 39491.84 & 92.08 \\
\hline 2016 & 3704.65 & 7.84 & 121.54 & 0.26 & 158.80 & 0.34 & 47251.36 & 43583.97 & 92.24 \\
\hline 2017 & 3716.85 & 7.18 & 106.76 & 0.21 & 166.19 & 0.32 & 51768.26 & 48110.84 & 92.94 \\
\hline
\end{tabular}

environmental pollution not only increases the cost of pollution control, but also harms human health and ecological environment.

3.2. Industrial Structure Analysis of Zhejiang Province from 2000 to 2017. With the development of social economy of Zhejiang Province, the GDP during 2000-2017 has grown substantially from 614.103 billion yuan in 2000 to 517.768 billion yuan in 2017. In the meantime, the industrial structure has undergone tremendous changes. The GDP of the primary industry (PI), which refers to the department that uses natural forces primarily to produce consumable products or industrial raw materials without further processing, increased from 63.098 billion yuan in 2000 to 193.392 billion yuan in 2017 , showing a slow growth phenomenon, but the proportion of the PI in GDP began to decrease from $10.27 \%$ in 2000 to that in 2017 . The proportion of GDP is only $3.74 \%$, reaching the lowest value of the PI in GDP from 2000 to 2017; the GDP of the secondary industry (SI), which is defined as the mining industry (excluding mining assistance activities), manufacturing (excluding metal products, machinery and equipment repair), electricity, heat, gas and water production and supply, and construction, increased from 327.393 billion yuan in
2000 to 232.328 billion yuan in 2017 , showing a slightly faster growth than the PI (Figure 2).

However, the proportion of the SI in GDP has decreased first, then increased, and then decreased year by year. The trend of volatility fell from $53.31 \%$ of GDP in 2000 to $51.11 \%$ in 2002 and then rose to $54.15 \%$ in 2006 and 2007, reaching the highest value of the SI in GDP during the period of 2000-2017, and has since declined. By 2017, the SI will account for $42.95 \%$ of GDP, the lowest value of the SI in GDP in the study period; the GDP of tertiary industry (TI) which referred to other industries except the PI and SI, such as wholesale and retail trade, transportation, warehousing, and postal services, increased rapidly from 226.612 billion yuan in 2000 to 2.760226 billion yuan in 2017 . With the GDP growth of the TI, it accounts for GDP. Excluding the decline in individual years, the overall growth trend is relatively fast. The proportion of TI in GDP increased from $36.41 \%$ in 2000 to $53.32 \%$ in 2017 . In 2014, the proportion of TI in GDP reached the first time in 15 years. Exceeding the SI's share of GDP, the TI has maintained a leading position in GDP since then. It can be seen that Zhejiang Province vigorously promoted the regulating of industrial structure and the development mode transformation during the period of 2000-2017 and optimized the industrial structure of Zhejiang Province. 


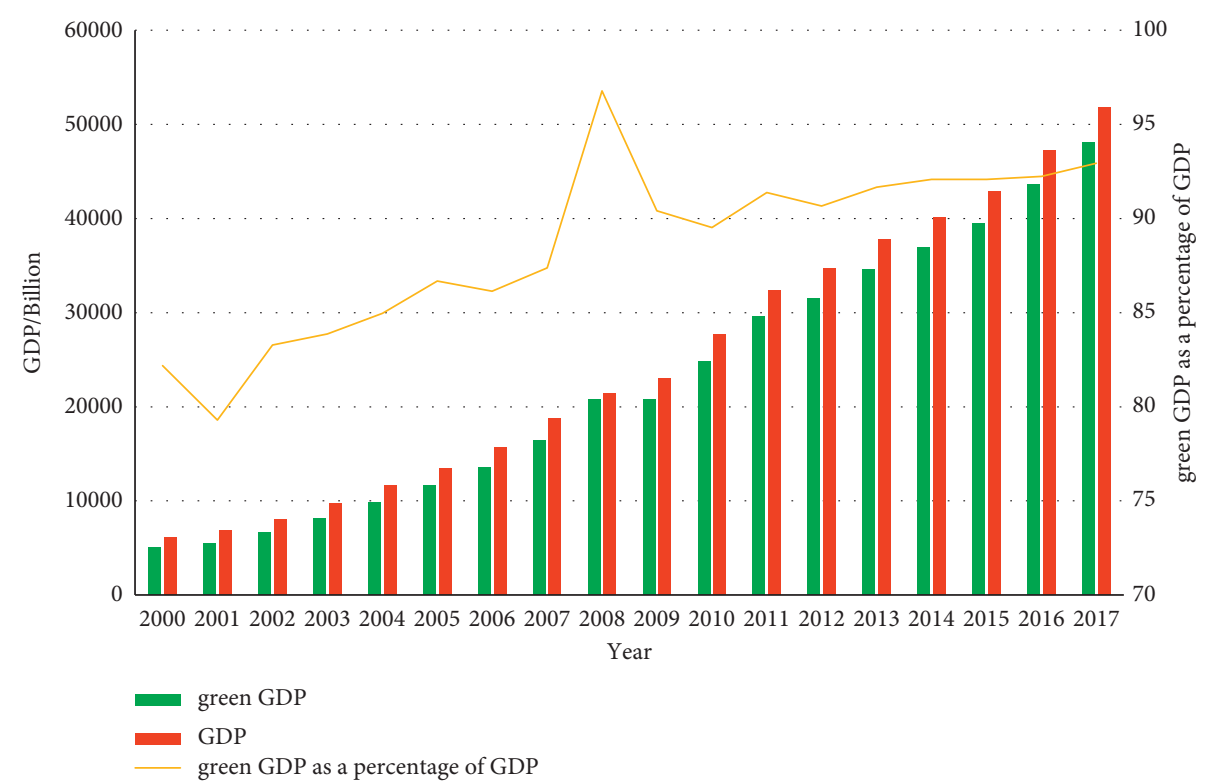

Figure 1: Zhejiang's GGDP, GDP, and GGDP as a share of GDP from 2000 to 2017.

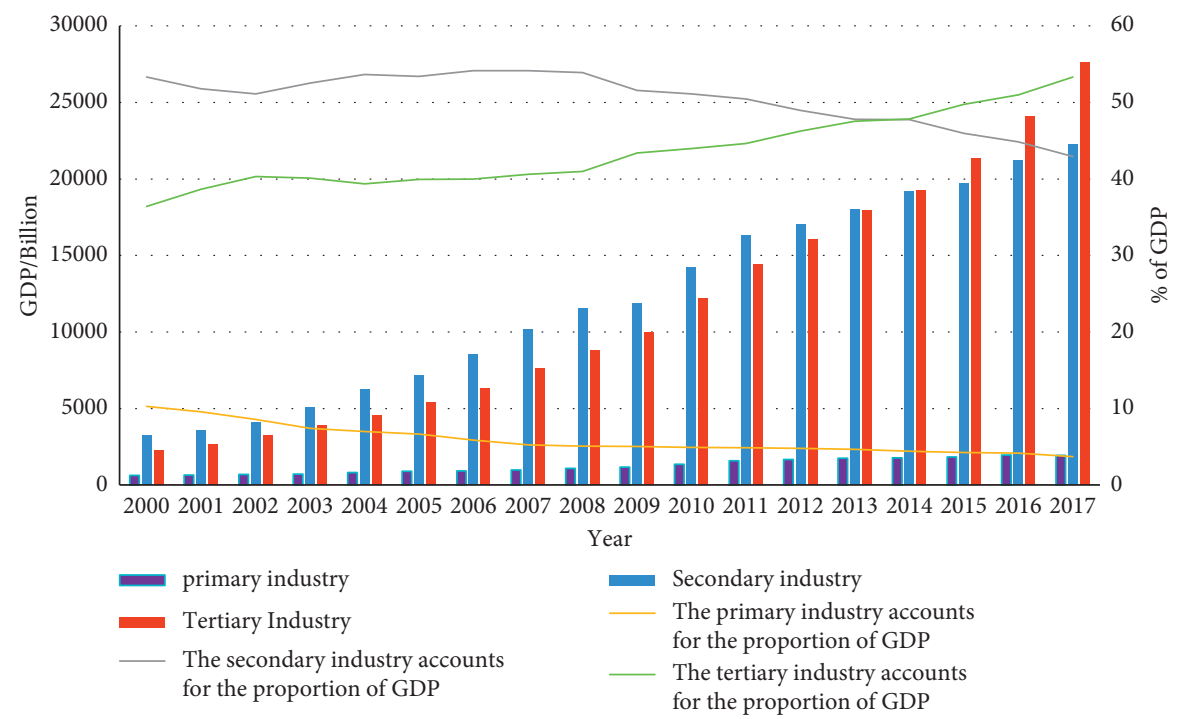

Figure 2: GDP of Zhejiang Province from 2000 to 2017.

\section{Conclusions}

Based on the data of Zhejiang Province from 2000 to 2017, this study calculates the GGDP in the past 18 years by constructing a GGDP accounting system and draws the following conclusions:
(1) During the period of 2000-2017, the GGDP and GDP of Zhejiang Province maintained a simultaneous growth. The GGDP accounted for $79.29 \%-96.78 \%$ of GDP which showed a volatility upward trend, resulting from the significant environmental protection and conservation of natural resources in the study area. 
However, the depletion of natural resources still occupied a dominant position in GGDP. Economic development was particularly dependent on energy resources, and comprehensive utilization of resources had to be strengthened. In a word, the economic development of Zhejiang Province has become less dependent on resources and environment, and the economic development model was gradually optimized.

(2) During the period of 2000-2017, the industrial structure of Zhejiang Province experienced significant changes. The proportion of the PI has been decreasing, and the proportion of the SI fluctuated and declined year by year. The TI showed volatility, surpassing the second after 2014. The proportion of industry and the proportion of the SI and TI were gradually widening, indicating that the economy of Zhejiang Province was transforming from an industry-led economy to a service-oriented economy. This trend was conducive to economic, social, and environmental sustainability development of Zhejiang Province.

(3) In 2008, the GGDP of Zhejiang Province accounted for the highest proportion of GDP during the period of 2000-2017 (Figure 1). The reasons were as follows. First, by analysing the Zhejiang Statistical Yearbook, it can be found that the area of cultivated land has increased significantly. It was the main reason. On the other hand, Zhejiang Province promulgated a number of policies on farmland protection around 2008, implemented strict farmland protection systems and land-saving systems, and adopted laws, economics, science, technology, etc. ways to maintain the red line of cultivated land protection and increase the intensity of land construction and land remediation. Second, due to the 2008 Beijing Olympic Games, the country had increased its focus on air quality, increased investment in environmental protection, improved environmental quality, and reduced environmental quality degradation costs. Third, scientific and technological progress had reduced the unit cost of pollutants and reduced the cost of environmental quality degradation. In sum, the result of a combination of relevant national policies and international competitions resulted in that the GGDP of Zhejiang Province accounted for the highest proportion of GDP during the study period.

\section{Data Availability}

All data, models, and code generated or used during the study appear in the submitted article.

\section{Conflicts of Interest}

The authors declare no conflicts of interest with respect to the research, authorship, and/or publication of this article.

\section{Acknowledgments}

This study was supported by the Open Research Fund of State Key Laboratory of Subtropical Silviculture, Zhejiang A\&F University (KF201706).

\section{References}

[1] Y. P. Li, "Change from development to GDP to green GDP," Truth Seeking, vol. 1, pp. 38-39, 2006.

[2] L. X. Wang and Z. Y. Ren, "An elementary discussion and analysis of green GDP calculation methods: a case study of Datong City in Shanxi Province," Progress in Geography, vol. 24, no. 2, pp. 100-105, 2005.

[3] M. L. Cao, L. L. Zhang, and H. Zha, "Experience and enlightenment of implementing green GDP accounting at home and abroad," Environmental Protection, vol. 4, pp. 63-65, 2014.

[4] Z. L. Zhao, "The new empirical example of local governance guiding by green GDP performance assessment," Journal of Huazhong University of Science and Technology (Nature Science Edition), vol. 6, pp. 6-10, 2017.

[5] B. F. Giannetti, F. Agostinho, C. M. V. B. Almeida, and D. Huisingh, "A review of limitations of GDP and alternative indices to monitor human wellbeing and to manage ecosystem functionality," Journal of Cleaner Production, vol. 87, pp. 11-25, 2015.

[6] W. X. Kang, D. Wang, J. L. Zou, Y. P. Hu, and S. S. Cui, "Accounting green GDP in Huaihua based on energy analytic approach," Acta Ecologica Sinica, vol. 30, no. 8, pp. 2151-2158, 2010.

[7] H. Jia and X. L. Yu, "The demonetized green GDP accounting system based on the MCDM," Journal of Arid Land Resources \& Environment, vol. 27, no. 8, pp. 6-13, 2013.

[8] European Commission, SERIEE European System for the Collection of Economic Information on the Environment 1994 Version, European Comission, Brussel, 2002.

[9] H. M. Peskin, "Alternative resource and environmental accounting approaches and their contribution to policy," Ecol. Econ, vol. 21, pp. 217-229, 1998.

[10] S. J. Keuning and M. D. Han, Netherlands: What's in a NAMEA? Recent Results, Springer, Amsterdam, Netherlands, 1998.

[11] R. Costanza, R. d'Arge, R. de Groot et al., "The value of the world's ecosystem services and natural capital," Nature, vol. 387, no. 6630, pp. 253-260, 1997.

[12] G. C. Daily, T. Soderqvist, S. Aniya et al., "ECOLOGY: the value of nature and the nature of value," Science, vol. 289, no. 5478, pp. 395-396, 2000.

[13] T. Peng and W. L. Wu, "Green GDP accounting: further research and discussion in the context of low-carbon development," China Popu. Resour. Environ, vol. 20, no. 12, pp. 81-86, 2010.

[14] H. M. Zhang and C. R. Qiu, "A framework analysis of the green GDP accounting system in China, Financ," Trade Res, vol. 3, pp. 37-42, 2004.

[15] N. Lin, "Green GDP accounting system and development of circular economy," Contemporary Economics, vol. 11, pp. 53-55, 2006.

[16] M. Lei, "Green GDP accounting," Journal of Natural Resources, vol. 13, no. 4, pp. 320-326, 1998.

[17] J. Li, Y. L. Kang, and Y. Lu, "An empirical study of green GDP accounting in Chengdu,” J. Soc. Sci, vol. 7, pp. 13-16, 2007. 
[18] R. X. Xiu, G. Wu, X. A. Zeng, J. G. Sun, and D. Y. Yu, "Research progress of green GDP accounting index," Chinese J. Ecol, vol. 26, no. 7, pp. 1107-1113, 2007.

[19] M. G. Chen, "A gross economic indicator under sustainable development: green GDP, China Popu," Resources and Environment, vol. 15, no. 1, pp. 1-6, 2005.

[20] Z. Wang, Y. Liu, and Q. B. Zhou, "Research on Shanghai's general growth accounting and green GDP accounting," Geographical Research, vol. 25, no. 2, pp. 185-192, 2006.

[21] M. Lei, X. Y. Zhang, and M. M. Cao, "Accounting research of green GDP of resource-dependent cities: a case study of Yulin City in Shaanxi Province," Journal of Natural Resources, vol. 24, no. 12, pp. 2046-2055, 2009.

[22] H. Zhang, M. S. Huang, and X. H. Hu, "Green GDP calculation of Fujian province based on energy analysis," Acta Geographica Sinica, vol. 65, no. 11, pp. 1421-1428, 2010.

[23] X. Y. Shen, G. H. Wang, and X. J. Huang, "Green GDP accounting and spatio-temporal pattern in China from 1997 to 2013," Journal of Natural Resources, vol. 32, no. 10, pp. 1639-1650, 2017.

[24] L. Y. Guo, M. Lei, and X. Q. Liu, "Green GDP accounting research based on emergy analysis method: a case study of Shangluo city in Shaanxi Province," Journal of Natural Resources, vol. 30, no. 9, pp. 1523-1533, 2015.

[25] L. Y. Ge, "Green GDP accounting based on sustainable development," Statistics \& Decisions, vol. 17, pp. 27-29, 2013.

[26] M. Lei, "Trial estimate of 1995' CSEEA and Chinese green GDP,” Syst. Eng. Theor. Pr, vol. 20, no. 11, pp. 1-9, 2000.

[27] Z. Y. Jin and X. J. Huang, "Accounting of the green GDP in Jiangsu Province based on values of resources and environment," Areal Res. Dev, vol. 33, no. 4, pp. 131-135, 2014.

[28] D. Z. Liu, G. E. Zou, and H. Qin, "Empirical study on green GDP accounting in Hebei Province," J. Hebei GEO Univ, vol. 29 , no. 5, pp. 620-623, 2006.

[29] Y. J. Lou and L. Q. Jin, "An empirical study of green GDP accounting system on Hangzhou," Reformation Strateg, vol. 26 , no. 10 , pp. $122-124,2010$.

[30] X. Z. Xu and S. B. Yan, "Research and application of green GDP accounting in Fujian Province," J. Anhui Agr. Sci, vol. 39, no. 19, pp. 11806-11808, 2011.

[31] Y. M. He and S. S. Wu, "Construction of green GDP accounting system based on resource value loss method," Statistics \& Decisions, vol. 17, pp. 5-10, 2017.

[32] G. L. Guo, Study ongreen GDP accounting adjusted by environment pollution losses and a case analysis, Master's thesis, Wuhan University of Technology, Wuhan, China, 2006.

[33] W. J. Zhang, F. Zhang, Z. Yan, and Z. H. Zhang, "Initial Analysis on the ecological service value of the greening land in Lanzhou city," Pratacultural Science, vol. 23, no. 11, pp. 98-102, 2006. 